\title{
Teljes körű iskolai egészségfejlesztési koncepció
}

\author{
Whole school health promotion concept
}

\author{
Szerző: $\quad$ Solymosy József Bonifácz $\square$ \\ Nemzeti Egészségfejlesztési Intézet
}

Kulcsszavak: teljes körü; iskolai; egészségfejlesztés

Keywords: whole approach; school; health promotion

A Nemzeti Egészségfejlesztési Intézet (a továbbiakban: NEFI) és a Klebelsberg Intézményfenntartó Központ (a továbbiakban: KLIK) a Kormányzattól kapott felhatalmazással' élve 2014. augusztus és 2015. november között megvalósította a „TIE-Projektet”.i A projekt keretében - sok más egyéb eredmény mellett - több egészségfejlesztési témát, programot lefedő szakmai ajánlás, módszertani szakanyag készült, valamint a teljes körú iskolai egészségfejlesztés szakmai koncepciója (a továbbiakban: Koncepció). A Koncepcióiii elsősorban az országos és a helyi döntéshozók számára készült azzal a céllal, hogy a szakpolitikai, egyben kormányzati döntéshozatalt támogassa, és döntés-előkészítő anyagként szolgáljon az elkövetkező időszakban, de legalább 2020-ig. Ezen túlmenően a Koncepció olyan eszközöket is igyekszik adni a döntéshozók kezébe, amelyek segítenek az iskolák életében meglévő változási folyamatok útjában álló akadályok legyőzésében. A Koncepció ennek érdekében világos helyzetelemzést ad, célokat és gyakorlatban alkalmazható beavatkozási és intézkedési javaslatokat fogalmaz meg a Projekt célrendszerével és a szakpolitikai stratégiai irányokkal összhangban.

\section{AZ ALÁBBIAKBAN A KONCEPCIÓ FŐ FEJEZETEI- NEK CÉLÁT TEKINTJÜKK ÁT}

A Bevezetés című fejezet meghatározza a teljes dokumentum célját, valamint bemutatja a Koncepció megalapozottságát és indokoltságát. A Helyzetelemzés címú fejezet bemutatja a Koncepció számára releváns célcsoport egészségi állapotát jellemző demográfiai (születés, halálozás) és megbetegedési adatokat, valamint bemutatja az életmódra vonatkozó adatokat is az ezeket alátámasztó kutatásokkal együtt. A hazai és nemzetközi iskolai egészségfejlesztés története mellett a fejezet kitér a más területeket is érintő jogszabályi környezetre, az elindult fejlesztésekre, valamint röviden bemutatja azokat a Kormány által elfogadott stratégiákat, amelyek valamilyen formában kapcsolódnak az iskolai egészségfejlesztéshez. A fejezet végén a jelenlegi helyzetet leíró „problémafa”, valamint a stratégiai irányokat meghatározó SWOT elemzés kerül bemutatásra. Az Elméleti és módszertani háttér címú fejezet célja, hogy a Helyzetelemzés című fejezetben leírt, elsősorban nemzetközi példák alapján öszszefoglalja azokat az alapokat, amelyek segítségével

\footnotetext{
i A Kormány a projektjavaslat támogatásának jóváhagyásáról és akciótervi nevesítéséről szóló 1467/2014 (VIII.15.) Korm. határozattal fogalmazta meg azt az elvárását, hogy a teljes körű iskolai egészségfejlesztés koncepciójának elkészítését (a továbbiakban: Koncepció) a kiemelt projekt keretében, a NEFI által vezetett konzorcium készítse el.

ii „TIE-Projekt”: „Komplex intézményi mozgásprogramok és kapcsolódó egészségfejlesztési alprogramok megvalósítása az általános iskolákban, valamint szabadidős közösségi mozgásprogramok és kapcsolódó egészségfejlesztési alprogramok megvalósítása az iskolán kívüli szereplők bevonásával” című, TÁMOP-6.1.2.A-14/1-2014-0001 jelű kiemelt projekt.

iii A Koncepció formai és tartalmi elemeit a kormányzati stratégiai irányításról szóló 38/2012. (III. 12.) Korm. rendelet (a továbbiakban 38/2012. (III.12.) Korm. rendelet) 33.§ írja le, amely alapján a hosszú távú koncepció egy adott szakpolitikai területról készült részletes stratégiai tervdokumentum, amely azonosítja a szakpolitikai területtel kapcsolatos legfontosabb problémákat; meghatározza a jövőképet és a jövőképen alapuló kiemelt célokat, valamint a beavatkozásokat, kockázatokat és a fontosabb eszközöket.
} 
a teljes körű iskolai egészségfejlesztés főbb célterületei és a megvalósításukhoz szükséges beavatkozások meghatározhatók. A Teljes körű iskolai egészségfejlesztés elvei címú fejezet bemutatja az egészségfejlesztés során alkalmazott elvek értelmezését az iskolai színtér tekintetében. A Jövőkép című fejezet célja, hogy a fentebb bemutatott helyzetelemzés és problémafa alapján bemutassa a gyakorlatban megvalósuló teljes körű iskolai egészségfejlesztés jövőbeni vízióját, felvázolva az elérendő állapotot. A Célterületek címú fejezet a korábban bemutatott modellek alapján a lehetséges változtatási célokkal együtt leírja azokat a célterületeket, amelyeken a beavatkozások hatásos és hatékony iskolai egészségfejlesztést eredményeznek. A Beavatkozások és szakpolitikai eszközök című fejezet célja bemutatni, hogy a felvázolt „Viselkedésváltoztatás ke- reke" modell szerint alkalmazott beavatkozások és szakpolitikai eszközök a célterületeken hogyan használhatóak fel kormányzati szinten. A fejezet továbbá tartalmazza a beavatkozások és a célterületek közötti koherenciák bemutatását, valamint a már meglévő és lehetséges ágazatközi kapcsolatokat. A Koncepció szerves részét képezi a 12 darab melléklet is. A Mellékletek című fejezet csak elektronikusan érhető el. A mellékletekben a fogalmak értelmezésén túl azok az anyagok találhatóak meg, amelyek pontosabban és részletesebben kifejtik és magyarázzák az összefüggéseket. Valamennyi fejezetben külön feltüntettük a legfontosabb hivatkozásokat, amelyek lehetővé teszik, hogy a terület iránt mélyebben érdeklődők is utánanézhessenek, vagy bővebben olvashassanak egy-egy hivatkozásról.

Stratégiai dokumentumnak hívunk minden olyan dokumentumot, amely a stratégiai tervezés különböző szintjein a tervezési folyamat végső kimeneteként keletkezik, például, koncepció, stratégia, akcióterv. A koncepció önmagában is értelmezhető stratégiai dokumentum, amely a stratégia átfogó, magas szintű megalapozását adja. A koncepció egy meghatározott területről készült részletes, a beavatkozások indokoltságát alátámasztó elméleti dokumentum, amely azonosítja a területtel kapcsolatos legfontosabb problémákat, meghatározza a jövőképet, továbbá a jövőkép elérését biztosító felső szintű célokat és prioritásokat. A koncepció a stratégiától abban különbözik, hogy nem tartalmazza a tervezett beavatkozásokat, az eszközök meghatározását, a pénzügyi tervezést és a megvalósítási-monitoring alapelveket, csupán ezek szakpolitikai megalapozását. A koncepcióban megfogalmazott célállapot (jövőkép) elérésének átfogó terve a stratégia: olyan, a koncepciónál részletesebb, ugyanakkor a koncepciót is magába foglaló stratégiai dokumentum, amely a jövőkép megalapozáson túl a jövőkép eléréséhez szükséges célhierarchiát, a tervezett konkrét beavatkozásokat (eszközöket), illetve a célok eléréséhez szükséges pénzügyi tervezést és megvalósítási-monitoring mechanizmusokat mutatja be. Az akcióterv olyan, a stratégia megvalósítására fókuszáló tervezési dokumentum, amely tartalmazza a stratégiai célok eléréséhez szükséges feladatokat, valamint a feladatok végrehajtására megállapított határidőket és felelősöket. A program (vagy akcióprogram) az akcióknak egy logikailag összetartozó csoportja. 